\title{
PSICOLOGIA DO TRABALHO: Uma intervenção em uma instituição hospitalar
}

\author{
Amanda Flávia Gonçalves Lima ${ }^{1}$ \\ Daniele Tavares de Oliveira ${ }^{1}$ \\ Ian Cesar Pereira ${ }^{1}$ \\ Leticia Gomes de Azevedo Soares ${ }^{1}$ \\ Constance Rezende Bonvicini ${ }^{2}$
}

\section{RESUMO}

INTRODUÇÃO: Intervir em um ambiente onde a relação entre colegas de trabalho, não importando a hierarquia, está comprometida, não é tarefa fácil, porém não é impossível. A Psicologia Organizacional existe exatamente para esse tipo de situação, melhorar o convívio dos indivíduos numa empresa, sendo ela pública ou privada visando formas para que tanto a empresa quanto os colaboradores que dela fazem parte saiam satisfeitos, pois só assim será possível desenvolver um bom trabalho para os que precisam fazer uso do serviço. OBJETIVO: Levantar dados sobre a instituição através da elaboração e aplicação de questionário de diagnóstico organizacional e desenvolver a equipe de acordo com sua demanda. MÉTODO: Este estudo consiste em um relato de experiência vivenciado pelos estagiários de Psicologia Organizacional do Trabalho, do Curso de Graduação em Psicologia da Faculdade Patos de Minas, no período de Fevereiro de 2017 a Novembro de 2017.

Inicialmente, para coleta de dados foram feitas observações à instituição, a respeito das condições e organização do trabalho; elaborou-se entrevista direcionada aos vinte cinco servidores do hospital com questões sobre os aspectos do cotidiano do trabalho e após aplicação das entrevistas sugeriu-se intervenção com workshop sobre habilidades sociais, humanização e burnout no setor público de saúde. O estágio profissionalizante de Psicologia Organizacional e do Trabalho apresenta como objetivo geral, dedicar ao estudo, concepção, avaliação e reestruturação das atividades laborais. RESULTADOS: Os dados levantados da entrevista (que constou de quatorze questões abertas) possibilitaram

\footnotetext{
${ }^{1}$ Acadêmicos do curso de psicologia da Faculdade Patos de Minas - FPM.

${ }^{2}$ Docente do departamento de psicologia da Faculdade Patos de Minas - FPM. E-mail: constancebonvicini@yahoo.com.br
} 
a identificação de conflitos: ao que concerne o Clima Organizacional e no tocante as relações hierárquicas e entre os pares. Quanto à estrutura física, notou-se melhoria nesses meses em que foi realizado o estágio, o hospital está passando por uma reforma, melhorando todo o espaço destinado ao atendimento aos pacientes. Quanto à liderança, essa se mostrou aberta a mudanças quanto à forma de gerir sua equipe. DISCUSSÃO: O termo liderança foi diretamente relacionado às pessoas que ocupavam a posição de gerenciamento e chefia. No entanto torna-se mister a necessidade de diferenciar um termo do outro, pois a liderança produz mudança e movimento nas organizações já a gerência apenas administra pessoas. $O$ líder cria uma visão, proporciona o alinhamento dos valores das pessoas aos valores da organização, desenvolvendo estratégias bem como a responsabilizando, inspirando e motivando o grupo. Quem gerencia apenas aplica ordem através do desenvolvimento do planejamento em curto prazo, controle e resolução de problemas. CONSIDERAÇÕES FINAIS: Através de levantamentos de dados os estagiários perceberam que havia empecilhos físicos e psicológicos para a equipe trabalhar de forma eficaz. Direcionou-se uma devolutiva técnica ao coordenador da instituição, que aderiu às observações positivas e negativas a respeito do Clima Organizacional, aceitando como intervenção um workshop com temas direcionados às habilidades sociais, humanização e burnout no sistema de saúde, que contou com a participação todos os funcionários do hospital. Observando-se melhorias em aspectos físicos e mudanças partidas do próprio líder em relação a sua postura profissional perante a equipe.

Palavras-chave: Hospital; Conflito; Psicologia Organizacional. 